Kenzo Kaneko • Yutaka Nagasaki • Toru Furukawa

Hiroya Mizutamari • Akihiko Sato $\cdot$ Atsushi Masamune

Tooru Shimosegawa $\cdot$ Akira Horii

\title{
Analysis of the human pancreatic secretory trypsin inhibitor (PSTI) gene mutations in Japanese patients with chronic pancreatitis
}

Received: November 28, 2000 / Accepted: February 1, 2001

\begin{abstract}
Chronic pancreatitis (CP) is a continuing or relapsing inflammatory disease of the pancreas. Several studies have demonstrated that mutations in the cationic trypsinogen (PRSS1) gene and the cystic fibrosis transmembrane conductance regulator (CFTR) gene are causative of the pathogenesis in a subset of hereditary and/or idiopathic $\mathrm{CP}$ cases. Recently, the N34S alteration of the pancreatic secretory trypsin inhibitor (PSTI) gene has been suggested to be closely associated with the pathogenesis of hereditary and/or idiopathic CP. Herein we analyzed genetic alterations of the PSTI gene in 32 unrelated Japanese CP patients who developed juvenile-onset $\mathrm{CP}$ or had a family history of CP; 5 patients were found to harbor alterations in this gene. In 3 of these 5 patients, heterozygous N34S alterations were found; this frequency is significantly lower than that in Caucasian patients reported previously. Moreover, a novel homozygous G-to-A transition in the promoter region of PSTI at $215 \mathrm{bp}$ upstream from the translation initiation site $(-215 \mathrm{G}>\mathrm{A})$ was observed in 2 patients. We further surveyed the $-215 \mathrm{G}>\mathrm{A}$ alteration in 117 normal individuals; none of these individuals harbored this alteration. Our results suggested that the $-215 \mathrm{G}>\mathrm{A}$ alteration, as well as the $\mathrm{N} 34 \mathrm{~S}$ alteration, is a predisposing factor for CP.
\end{abstract}

Key words Chronic pancreatitis - Familial pancreatitis . Hereditary pancreatitis · Idiopathic pancreatitis · Juvenile pancreatitis . Genetic alteration - Pancreatic secretory trypsin inhibitor (PSTI)

K. Kaneko · T. Furukawa $\cdot$ A. Horii $(\bowtie)$

Department of Molecular Pathology, Tohoku University School of Medicine, 2-1 Seiryo-machi, Aoba-ku, Sendai 980-8575, Japan Tel. +81-22-717-8042; Fax +81-22-717-8047

e-mail: horii@mail.cc.tohoku.ac.jp

K. Kaneko · Y. Nagasaki · H. Mizutamari · A. Sato · A. Masamune T. Shimosegawa

Department of Gastroenterology, Tohoku University School of

Medicine, Sendai, Japan

\section{Introduction}

It is generally believed that the aberrant intraductal activation of zymogens by trypsin leads to the autodigestion of the pancreas that causes pancreatitis, and that two different major protective mechanisms prevent inappropriate activation of the pancreatic digestive enzyme cascade. One mechanism is the pancreatic secretory trypsin inhibitor (PSTI), which inhibits up to $20 \%$ of potential trypsin activity (Laskowski and Kato 1980), and the other is the degradation and inactivation, by themselves, of active trypsin and other trypsin-like enzymes, such as mesotrypsin and enzyme Y (Rinderknecht 1986).

Chronic pancreatitis (CP) is a disease that probably arises from a multiple pathogenesis, which can include alcohol abuse, hyperlipidemia, hypercalcemia, cholecystolithiasis, genetic abnormality, and idiopathic. Previous reports indicated an association between hereditary/ idiopathic CP and mutations in the cystic fibrosis transmembrane conductance regulator (CFTR) gene (Cohn et al. 1998; Sharer et al. 1998), the cationic trypsinogen (PRSS1) gene (Whitcomb et al. 1996; Gorry et al. 1997; Ferec et al. 1999; Witt et al. 1999), and the PSTI gene (Pfutzer et al. 2000; Witt et al. 2000). The human PSTI gene on chromosome 5 is approximately $7.5 \mathrm{~kb}$ long and consists of four exons (Horii et al. 1987). This gene encodes a protein of 79 amino acid residues, including a signal peptide consisting of 23 amino acids (Yamamoto et al. 1985). An association between sporadic pancreatitis and PSTI alterations was tentatively excluded by Chen et al. (2000) in a study of French hereditary and sporadic CP patients. However, Witt et al. (2000) reported a strong correlation between PSTI alterations and CP; 22 (23\%) of 96 unrelated German children and adolescents with CP were found to have genetic alterations in exons and introns of PSTI, the majority being N34S and P55S. Based on these observations, Witt et al. concluded that these were, presumably, causative mutations of idiopathic CP. Recently, Pfutzer et al. (2000) analyzed American and European patients and confirmed the positive association between hereditary/ 
idiopathic pancreatitis and the PSTI alterations; either N34S or P55S alterations were observed in 29 (26\%) of 112 patients. As the PSTI alterations were found to be relatively rare in the general population (only 5 (3\%) of 190 individuals; three N34S and two P55S), the significantly high frequency in the idiopathic CP patients $(P<0.001)$ supported the possibility of a pathogenic role. The age of onset and severity were basically the same, irrespective of homozygosity or heterozygosity. Based on the information above, we started a genomic analysis of PSTI in Japanese $\mathrm{CP}$ patients.

\section{Subjects and methods}

Patients and control individuals

A total of 32 (15 males and 17 females) unrelated CP patients with family histories of CP or with juvenile-onset disease who bore no mutations in PRSS1, were enrolled in this study. Eleven patients (34\%) had a family history of CP, $24(75 \%)$ had juvenile-onset $\mathrm{CP}$, and $23(72 \%)$ had idiopathic $\mathrm{CP}$. The mean age of onset was 27 years (range, 5 to 63 years). Diagnosis of CP was made according to the diagnostic criteria for CP (Homma 1998), consisting of imaging tests, such as abdominal ultrasonography, computed tomography (CT) scan; and endoscopic retrograde cholangiopancreatography (ERCP); an exocrine test, such as the secretin test; and histologic examination. DNAs from peripheral blood cells of 117 healthy volunteers served as controls for the genetic analysis of PSTI. The patients and control subjects enrolled in this study were all Japanese and all had given informed consent. This study was approved by the Ethical Committee of Tohoku University School of Medicine.

Nucleotide sequencing analysis

Genomic DNA was extracted from peripheral blood leukocytes according to the standard protocol (Sambrook et al.
1989). We performed the first polymerase chain reaction (PCR) amplification for the promoter and each exonic region, as well as the flanking exon/intron boundary, by employing the primers designed according to a previous study (Witt et al. 2000). Subsequently, we performed the second PCR amplification, using 1:400 dilutions of the respective first PCR products and the internal primers described below. Nucleotide sequences of the primers and conditions for the PCR amplifications are summarized in Table 1. PCR was carried out as described previously (Mori et al. 1997) in a total volume of $25 \mu \mathrm{l}$. The cycle conditions were as follows: initial denaturation for $2 \mathrm{~min}$ at $95^{\circ} \mathrm{C}$; followed by either 30 cycles (for first PCR amplification) or 20 cycles (for second PCR amplification) of the following regimen: 30 s of denaturation at $95^{\circ} \mathrm{C}, 30 \mathrm{~s}$ of annealing at $60^{\circ} \mathrm{C}$, and $30 \mathrm{~s}$ of extension at $72^{\circ} \mathrm{C}$. A final extension for $5 \mathrm{~min}$ at $72^{\circ} \mathrm{C}$ was also added. Nucleotide sequences of the second PCR products were analyzed by the methods described previously (Sakurada et al. 1997), using a BigDye terminator cycle sequence ready kit (Applied Biosystems; Foster City, CA, USA) and an ABI 310 Genetic Analyzer (Applied Biosystems).

PCR restriction fragment length polymorphism (RFLP) analysis

To confirm the genetic alterations in the promoter region $(-253 \mathrm{~T}>\mathrm{C}$ and $-215 \mathrm{G}>\mathrm{A})$ and exon $4(272 \mathrm{C}>\mathrm{T})$, second $\mathrm{PCR}$ products were digested by appropriate restriction enzymes as recommended by the manufacturers; $-253 \mathrm{~T}>\mathrm{C}$, by $B g l \mathrm{I} ;-215 \mathrm{G}>\mathrm{A}$, by $B g l \mathrm{I}$; and $272 \mathrm{C}>\mathrm{T}$, by $B s t \mathrm{U} 1$. The digested fragments were then electrophoresed on a $5 \%$ acrylamide gel.

Statistical analysis

Statistical analysis was carried out with Fisher's probability test as appropriate.

Table 1. PCR primers used in this study

\begin{tabular}{|c|c|c|}
\hline & Sense primer & Antisense primer \\
\hline \multicolumn{3}{|l|}{ First PCR } \\
\hline Promoter & 5'-TTTGAGTTCATCTTACAGGTGAG-3' & 5'-TATGGCAGATGGCAGCAAGG-3' \\
\hline Exon 1 & 5'-CCAGGCTATGACACAGAGTC-3' & 5'-GTGCTTCACAAAGCAACAGGTC-3' \\
\hline Exon 2 & 5'-GGGTGGGGAATGAAAGAGCC-3' & 5'-AAAGGTGACAGCAAGGCTGC-3' \\
\hline Exon 3 & 5'-CCAATCACAGTTATTCCCCAGAG-3' & 5'-GTTTGCTTTTCTCGGGGTGAG-3' \\
\hline Exon 4 & 5'-CCCTGTTTTTCTCCCATAGTCAC-3' & 5'-CCAAAGTCCCCTGACCCTGG-3' \\
\hline \multicolumn{3}{|l|}{ Second PCR } \\
\hline Promoter & 5'-GAGAAAACAGGCTTGAGAAGG-3' & 5'-CCTACTGGGCTATATCACAGA-3' \\
\hline Exon 1 & 5'-GTCAATCAATAACCAGGGAGAT-3' & 5'-AAAGCAACAGGTCAAAACAGTT-3' \\
\hline Exon 2 & 5'-TCACAGTCTGCAATGAAAGCAG-3' & 5'-GCATTTTTGTTGGATCAAACTG-3' \\
\hline Exon 3 & 5'-CCATTTCAGAGATTTTGCTATG-3' & 5'-GGTGAGATTCATATTATCAGTA-3' \\
\hline Exon 4 & 5'-CCCATAGTCACTTTTTCATCAG-3' & 5'-TGACCCTGGTATAATCAAACAT-3' \\
\hline
\end{tabular}

PCR, Polymerase chain reaction

Annealing temperature for all primer sets are $60^{\circ} \mathrm{C}$ 


\section{Results and discussion}

We investigated the whole exonic region, along with the flanking intronic sequences (about up to $10 \mathrm{bp}$ from the exon/intron junction), as well as the promoter region of the PSTI gene, by direct DNA sequencing in 32 Japanese $\mathrm{CP}$ patients, and detected four different types of alterations. Examples of the nucleotide sequencing analyses are shown in Fig. 1. A heterozygous A-to-G transition in the second nucleotide of codon 34 in exon 3 , the 11th amino acid in the mature peptide, was observed in case 62 (see Fig. 1A). This alteration (from AAT to AGT) would cause an amino acid change from Asn to Ser (N34S). This type of alteration was found in two other unrelated CP patients (cases 51 and 54). Besides the N34S alteration, a homozygous G-to-A transition in the promoter region of the PSTI gene at $215 \mathrm{bp}$
(A)
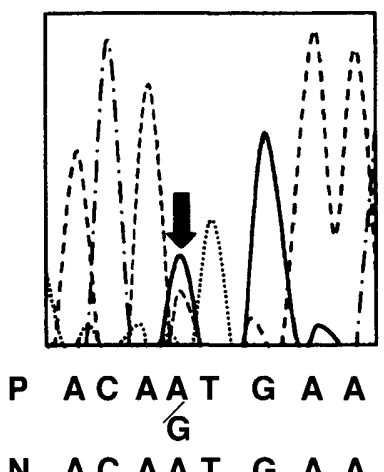

(B)

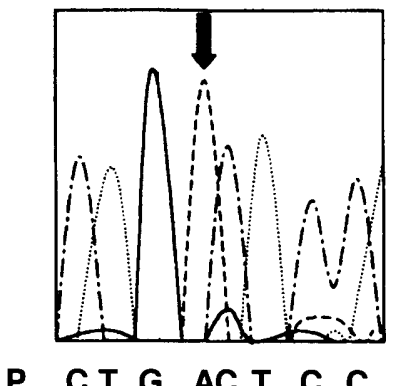

P CT G ACT C C
N ACAAT G A A

Fig. 1. A Nucleotide sequences of sense strand of exon 3 of human PSTI in case 62, a patient with idiopathic chronic pancreatitis (CP). Heterozygosity of $\mathrm{A} / \mathrm{G}$ at the second nucleotide of codon 34 was found, which would cause an amino acid alteration from Asn to Ser (N34S). This genetic alteration was also observed in two other affected patients (cases 51 and 54), but not in any of the 32 normal individuals. $P$ and $N$ denote the nucleotide sequences of the patient (case 62) and a normal individual, respectively. B Nucleotide sequences in the promoter region of PSTI in case 60, a patient with idiopathic CP. A homozygous A residue instead of $\mathrm{G}$ at nucleotide 215 upstream from the translation initiation site $(-215 \mathrm{G}>\mathrm{A})$ was shown in another affected patient (case 35 ), but not in any of the 32 normal individuals. $P$ and $N$ denote nucleotide sequences of the patient (case 60) and a normal individual, respectively. Arrows in $\mathbf{A}$ and $\mathbf{B}$ indicate altered nucleotides

upstream from the translation initiation site (hereinafter, $-215 \mathrm{G}>\mathrm{A}$ ) was observed in two patients (cases 35 and 60). Results of the nucleotide sequencing analysis in case 60 are shown in Fig. 1B. These results, along with patients' clinical information, are summarized in Table 2. We further examined the DNA samples from healthy volunteers by direct sequencing (32 samples for N34S) and by PCR RFLP analysis (117 samples for $-215 \mathrm{G}>\mathrm{A})$, but neither $\mathrm{N} 34 \mathrm{~S}$ nor $-215 \mathrm{G}>\mathrm{A}$ was found.

We observed no other disease-associated alterations in PSTI in the patients examined. Reported single-nucleotide polymorphisms (SNPs), a heterozygous alteration of $-253 \mathrm{~T}>\mathrm{C}$ (a T-to-C transition at $253 \mathrm{bp}$ upstream from the translation initiation site), and a heterozygous alteration of $272 \mathrm{C}>\mathrm{T}$ (a C-to-T transition at the $272 \mathrm{nd}$ base from the translation initiation site that is in the $3^{\prime}$ untranslated region), were detected in 6 and 5, respectively, of the 32 patients. The $-253 \mathrm{~T}>\mathrm{C}$ and $272 \mathrm{C}>\mathrm{T}$ polymorphisms were detected in 10 and 4, respectively, of 32 control individuals. Two of these alterations, $-215 \mathrm{G}>\mathrm{A}$ and $272 \mathrm{C}>\mathrm{T}$, were confirmed by PCR-RFLP (data not shown).

The $-215 \mathrm{G}>\mathrm{A}$ alteration found in our study has never been reported previously. Probably, this mutation is rare in Caucasians. This alteration was not found in any of the 117 healthy volunteers; the frequency of this alteration in our CP patients was significantly higher than that in normal individuals $(P=0.045)$. However, we cannot totally rule out the possibility of a rare polymorphism. On the other hand, no heterozygotes for this alteration were found in either our $32 \mathrm{CP}$ patients or the 117 healthy volunteers; only $2 \mathrm{CP}$ patients were homozygous for the $-215 \mathrm{G}>\mathrm{A}$ alteration. This suggests that there may have been a sampling bias when the case population was selected. However, another explanation is also possible; individuals homozygous for the $-215 \mathrm{G}>\mathrm{A}$ alteration are much more likely to have $\mathrm{CP}$ than the heterozygous individuals and those without the alteration.

Witt et al. (2000) and Pfutzer et al. (2000) have reported a CP-associated alteration of N34S in PSTI in Caucasian patients. In the present study, we found the N34S alteration in this gene in three Japanese CP patients. From our survey of the literature, we believe this is the first report of the N34S alteration in Mongolians; the N34S alteration seems to be one of the predisposing factors for $\mathrm{CP}$, irrespective of race. Witt et al. (2000) analyzed 96 unrelated children and

Table 2. Data from subjects harboring the $\mathrm{N} 34 \mathrm{~S}$ or $-215 \mathrm{G}>\mathrm{A}$ alteration in this study

\begin{tabular}{|c|c|c|c|c|c|c|c|c|}
\hline $\begin{array}{l}\text { Case } \\
\text { no. }\end{array}$ & Alteration & $\begin{array}{l}\text { Allele } \\
\text { status }\end{array}$ & Clinical features & $\begin{array}{l}\text { Age at } \\
\text { onset }\end{array}$ & Sex & DM & $\begin{array}{l}\text { Calcification } \\
\text { in pancreatic } \\
\text { parenchyma }\end{array}$ & $\begin{array}{l}\text { Alcohol } \\
\text { intake }\end{array}$ \\
\hline 51 & N34S & ht & & 17 & $\mathrm{M}$ & + & - & - \\
\hline 54 & N34S & ht & & 11 & M & - & + & - \\
\hline 62 & N34S & ht & & 21 & M & - & + & - \\
\hline 35 & $-215 \mathrm{G}>\mathrm{A}$ & $\mathrm{hm}$ & $\begin{array}{l}\text { Family history of } \mathrm{CP} \\
\text { (brother) }\end{array}$ & 41 & M & + & + & + \\
\hline 60 & $-215 \mathrm{G}>\mathrm{A}$ & $\mathrm{hm}$ & $\begin{array}{l}\text { Anomalous union of bilio- } \\
\text { pancreatic ducts }\end{array}$ & 7 & $\mathrm{~F}$ & - & - & - \\
\hline
\end{tabular}

DM, Diabetes mellitus; ht and hm, heterozygous and homozygous, respectively 
Table 3. Ratios and frequencies of the N34S mutation in the PSTI gene of CP patients

\begin{tabular}{|c|c|c|c|c|c|c|c|}
\hline & & \multicolumn{2}{|c|}{ This study } & \multicolumn{2}{|c|}{ Witt et al. (2000) } & \multicolumn{2}{|c|}{ Pfutzer et al. (2000) } \\
\hline & & Patient & Control & Patient & Control & Patient & Control \\
\hline \multirow[t]{2}{*}{ Per patient } & Ratio & 0.09 & 0 & 0.19 & 0.004 & 0.25 & 0.016 \\
\hline & Frequency & $3 / 32$ & $0 / 32$ & $18 / 96$ & $1 / 279$ & $28 / 112$ & $3 / 190$ \\
\hline \multirow[t]{2}{*}{ Per allele } & Ratio & 0.05 & 0 & 0.13 & 0.002 & 0.16 & 0.008 \\
\hline & Frequency & $3 / 64$ & $0 / 64$ & 24/192 & $1 / 558$ & $35 / 224$ & $3 / 380$ \\
\hline
\end{tabular}

The ratios and frequencies reported by various groups are shown as per patient and per allele

$\mathrm{CP}$, Chronic pancreatitis

adolescents with CP; 28 patients (29\%) had a family history, and 68 patients $(71 \%)$ had idiopathic CP. Pfutzer et al. (2000) analyzed 120 patients, 59 (49\%) with familial, and 61 $(51 \%)$ with idiopathic pancreatitis. In the present study, we analyzed 32 unrelated CP patients; 11 patients $(34 \%)$ had at least one CP patient in the family, 24 patients $(75 \%)$ had juvenile-onset $\mathrm{CP}$, and 23 patients ( $72 \%$ ) had idiopathic $\mathrm{CP}$. Although there are some differences among the patients analyzed in these three studies, it is still valuable to compare the frequencies of N34S alterations in the three studies statistically. The ratios of N34S alterations in the sample populations reported in these studies were 19\% (18/96), by Witt et al. (2000); and 25\% (28/112), by Pfutzer et al. (2000); but we found a ratio of only $9 \%(3 / 32)$ in our CP patients. These results are summarized in Table 3 . The frequency in the present study is significantly lower than that reported by Pfutzer et al. $(P=0.043)$, and a similar tendency was found, although the difference was not significant, between our frequency and that reported by Witt et al. (2000).

An X-ray crystallography-based model revealed that the 34th amino acid residue was located close to the reactive Lys-Ile site (41st and 42nd residues) of PSTI; accordingly, the mutation may lead to decreased inhibitory activity. Pfutzer et al. (2000) proposed that the PSTI alterations were disease-modifying, rather than disease-causing, possibly by lowering the threshold for pancreatitis. Therefore, the $-215 \mathrm{G}>\mathrm{A}$ alteration may also lower the threshold for the development of pancreatitis, perhaps by reducing the transcriptional efficiency of PSTI. The promoter region of the PSTI gene does not contain the consensus sequence that is indispensable for the pancreas-specific expression of various genes, such as mouse $\alpha$-amylase 2 , elastase 2, trypsin, rat elastase I, and chymotrypsin B (Walker et al. 1983; Ornitz et al. 1985a; 1985b; Boulet et al. 1986), but it does have two unique positive elements for pancreas-specific expression (Yasuda et al. 1998), which exist between 116bp and $161 \mathrm{bp}$ upstream, and between $74 \mathrm{bp}$ and $103 \mathrm{bp}$ upstream from the translation initiation site. The $-215 \mathrm{G}>\mathrm{A}$ alteration discovered in this study is not located within these elements. However, there is the possibility that one base substitution, the $-215 \mathrm{G}>\mathrm{A}$, is located in an unknown cis-acting element and affects the efficiency of transcriptional activity of the PSTI gene, as was reported for the tumor necrosis factor- $\alpha(T N F-\alpha)$ gene within the binding site for monocytic and hepatic nuclear factors (Skoog et al. 1999).
Case 35, who harbored the $-215 \mathrm{G}>\mathrm{A}$ alteration, is a late-onset male patient with a family history of $\mathrm{CP}$ (brother). This patient had consumed a considerable amount of alcohol, $130 \mathrm{~g}$ every day for 26 years until the onset of disease; the relevance of alcohol in the pathogenesis was presumed. Because the exact cause(s) of alcoholassociated pancreatitis, one of the major types of $\mathrm{CP}$, is still unclear, it is worth determining whether or not these alterations of the PSTI gene exist in patients with alcoholicassociated pancreatitis, to shed light on the hypothesis that the PSTI alteration is disease-modifying, rather than disease-causing. Further investigation is required to clarify whether or not the $-215 \mathrm{G}>\mathrm{A}$ alteration has any influence on the expression of PSTI that may play a role in the pathogenesis of CP.

Acknowledgments We are grateful to Dr. Barbara Lee Smith Pierce (the Life Science Coordinator for the University of Maryland Asian Division) for editorial work in the preparation of this manuscript. This work was supported by Japanese Ministries of Education, Culture, Sports, Science, and Technology; and Health, Labour, and Welfare, and the Vehicle Racing Commemorative Foundation.

\section{References}

Boulet AM, Erwin CR, Rutter WJ (1986) Cell-specific enhancers in the rat exocrine pancreas. Proc Natl Acad Sci U S A 83:3599-3603

Chen JM, Mercier B, Audrezet MP, Ferec C (2000) Mutational analysis of the human pancreatic secretory trypsin inhibitor (PSTI) gene in hereditary and sporadic chronic pancreatitis. J Med Genet 37:6769

Cohn JA, Friedman KJ, Noone PG, Knowles MR, Silverman LM, Jowell PS (1998) Relation between mutations of the cystic fibrosis gene and idiopathic pancreatitis. N Engl J Med 339:653-658

Ferec C, Raguenes O, Salomon R, Roche C, Bernard JP, Guillot M, Quere I, Faure C, Mercier B, Audrezet MP, Guillausseau PJ, Dupont C, Munnich A, Bignon JD, Le Bodic L (1999) Mutations in the cationic trypsinogen gene and evidence for genetic heterogeneity in hereditary pancreatitis. J Med Genet 36:228-232

Gorry MC, Gabbaizedeh D, Furey W, Gates LK Jr, Preston RA, Aston CE, Zhang Y, Ulrich C, Ehrlich GD, Whitcomb DC (1997) Mutations in the cationic trypsinogen gene are associated with recurrent acute and chronic pancreatitis. Gastroenterology 113:1063-1068

Homma T (1998) Criteria for pancreatic disease diagnosis in Japan: diagnostic criteria for chronic pancreatitis. Pancreas 16:250-254

Horii A, Kobayashi T, Tomita N, Yamamoto T, Fukushige S, Murotsu T, Ogawa M, Mori T, Matsubara K (1987) Primary structure of human pancreatic secretory trypsin inhibitor (PSTI) gene. Biochem Biophys Res Commun 149:635-641

Laskowski M Jr, Kato I (1980) Protein inhibitors of proteinases. Annu Rev Biochem 49:593-626 
Mori Y, Shiwaku H, Fukushige S, Wakatsuki S, Sato M, Nukiwa T, Horii A (1997) Alternative splicing of hMSH2 in normal human tissues. Hum Genet 99:590-595

Ornitz DM, Palmiter RD, Hammer RE, Brinster RL, Swift GH, MacDonald RJ (1985a) Specific expression of an elastase-human growth hormone fusion gene in pancreatic acinar cells of transgenic mice. Nature 313:600-602

Ornitz DM, Palmiter RD, Messing A, Hammer RE, Pinkert CA, Brinster RL (1985b) Elastase I promoter directs expression of human growth hormone and SV40 T antigen genes to pancreatic acinar cells in transgenic mice. Cold Spring Harb Symp Quant Biol 50:399-409

Pfutzer RH, Barmada MM, Brunskill AP, Finch R, Hart PS, Neoptolemos J, Furey WF, Whitcomb DC (2000) SPINK1/PSTI polymorphisms act as disease modifiers in familial and idiopathic chronic pancreatitis. Gastroenterology 119:615-623

Rinderknecht H (1986) Activation of pancreatic zymogens. Normal activation, premature intrapancreatic activation, protective mechanisms against inappropriate activation. Dig Dis Sci 31:314-321

Sakurada A, Suzuki A, Sato M, Yamakawa H, Orikasa K, Uyeno S, Ono T, Ohuchi N, Fujimura S, Horii A (1997) Infrequent genetic alterations of the PTEN/MMAC1 gene in Japanese patients with primary cancers of the breast, lung, pancreas, kidney, and ovary. Jpn J Cancer Res 88:1025-1028

Sambrook J, Fritsh EF, Maniatis T (1989) Analysis and cloning of eukaryotic genomic DNA. In: Ford N, Nolan C, Ferguson M (eds) Molecular cloning, 2nd edn. Cold Spring Harbor Laboratory Press, New York, 9:16-23

Sharer N, Schwarz M, Malone G, Howarth A, Painter J, Super M, Braganza J (1998) Mutations of the cystic fibrosis gene in patients with chronic pancreatitis. N Engl J Med 339:645-652
Skoog T, van’t Hooft FM, Kallin B, Jovinge S, Boquist S, Nilsson J, Eriksson P, Hamsten A (1999) A common functional polymorphism $(\mathrm{C} \rightarrow$ A substitution at position -863) in the promoter region of the tumour necrosis factor-alpha (TNF-alpha) gene associated with reduced circulating levels of TNF-alpha. Hum Mol Genet 8:14431449

Walker MD, Edlund T, Boulet AM, Rutter WJ (1983) Cell-specific expression controlled by the $5^{\prime}$-flanking region of insulin and chymotrypsin genes. Nature 306:557-561

Whitcomb DC, Gorry MC, Preston RA, Furey W, Sossenheimer MJ, Ulrich CD, Martin SP, Gates LK Jr, Amann ST, Toskes PP, Liddle R, McGrath K, Uomo G, Post JC, Ehrlich GD (1996) Hereditary pancreatitis is caused by a mutation in the cationic trypsinogen gene. Nat Genet 14:141-145

Witt H, Luck W, Becker M (1999) A signal peptide cleavage site mutation in the cationic trypsinogen gene is strongly associated with chronic pancreatitis. Gastroenterology 117:7-10

Witt H, Luck W, Hennies HC, Classen M, Kage A, Lass U, Landt O, Becker M (2000) Mutations in the gene encoding the serine protease inhibitor, Kazal type 1, are associated with chronic pancreatitis. Nat Genet 25:213-216

Yamamoto T, Nakamura Y, Nishide J, Emi M, Ogawa M, Mori T, Matsubara K (1985) Molecular cloning and nucleotide sequence of human pancreatic secretory trypsin inhibitor (PSTI) cDNA. Biochem Biophys Res Commun 132:605-612

Yasuda T, Ohmachi Y, Katsuki M, Yokoyama M, Murata A, Monden M, Matsubara K (1998) Identification of novel pancreasspecific regulatory sequences in the promoter region of human pancreatic secretory trypsin inhibitor gene. J Biol Chem 273:3441334421 